\title{
Change does not happen overnight: a case study on stream macroinvertebrates
}

\author{
S. Guareschi ${ }^{1, \star \star \star \star}$, A. Laini ${ }^{2, \star \star}$, S. Fenoglio ${ }^{3}$, M. Paveto ${ }^{3}$ and T. Bo ${ }^{3}$ \\ 1 Department of Ecology and Hydrology, Regional Campus of International Importance "Campus Mare Nostrum" University of Murcia, \\ 30100 Murcia, Spain \\ 2 Department of Life Sciences, University of Parma, Parco Area delle Scienze 11/A, 43124 Parma, Italy \\ 3 Department of Science and Technological Innovation, University of Piemonte Orientale, Via T. Michel, 11, 15121 Alessandria, Italy
}

Received January 16, 2016 - Revised February 24, 2016 - Accepted February 24, 2016

\begin{abstract}
The influence of day/night conditions on individual animal/plant species has been widely studied, but diel cycle studies of the entire stream macroinvertebrate community are extremely rare. This study explored potential dissimilarities between daytime and nighttime macroinvertebrate assemblages by extensive fieldwork conducted in the Lemme stream, a natural water course of NW Italy. Here numerous structural and functional metrics (richness, abundance, biomass, indicator taxa, composition, biomonitoring values and feeding groups) were evaluated at the family level. Small-scale environmental variables were investigated to understand possible differences between macroinvertebrate assemblages in the daytime/nighttime. After collecting and identifying 21459 organisms of 50 taxa, Chironomidae (Diptera) was the most abundant under both day and night conditions. Our findings stressed that similar results and biological information on daytime/nighttime data were obtained. No marked differences could be related to various factors: heterotrophic condition of small-order streams, presence of aquatic predators under night and day conditions, absence of taxa with a specific phototaxis. Of all the environmental variables, velocity was always the most important in both situations, with some differences detected in the importance of the second variable (riverbed substrate diameter). This research, and future studies on different conditions and geographic areas, will contribute knowledge on stream macroinvertebrate diel activity, and provide useful information about efficient sampling strategies.
\end{abstract}

Key-words: aquatic ecology / diel cycle / lotic systems / aggregation / benthic invertebrates

Résumé - Le changement ne survient pas dans une nuit : étude sur la communauté de macro-invertébrés d'un cours d'eau. L'influence des conditions jour/nuit sur les espèces animales et végétales a été largement étudiée, tandis que les études à propos du cycle diurne de l'entier de la communauté des macro-invertébrées fluviales sont extrêmement rares. Dans le cadre de cette étude, les différences potentielles entre les assemblages de macro-invertébrés lors du jour et de la nuit ont été explorées grâce à un travail de terrain très appuyé. L'expérience a été conduite près du Lemme, un cours d'eau naturel situé dans le nord-ouest de l'Italie où des nombreux indicateurs structurels et fonctionnels (richesse, abondance, biomasse, taxons indicateurs, composition, valeurs de biosurveillance et groupes d'alimentation) ont été évalués au niveau Famille. Les variables environnementales à petite échelle ont été évaluées aussi dans le but de comprendre les différences possibles entre les assemblages de macro-invertébrés durant le jour et la nuit. Un total de 21459 organismes appartenant à 50 taxons ont été collectés et identifiés, montrant que le Chironomidae (Diptera) est le plus présent le jour comme la nuit. Nos trouvailles nous ont montré que des résultats similaires ont été obtenus dans des conditions diurnes comme nocturnes. L'absence de différences marquées peut être due à plusieurs facteurs, parmi lesquels les conditions hétérotrophes des cours d'eau de petite portée, la présence de prédateurs aquatique le jour comme la nuit et l'absence de taux avec phototaxie spécifique. En ce qui concerne les variables environnementales, la vitesse a été la plus importante dans le deux situations, alors que des différences ont été détectées avec le diamètre du substrat du lit du fleuve. Cette recherche, comme d'éventuels futures études portant sur différentes conditions et les zones géographiques, contribue à la connaissance de l'activité diurne de macro-invertébrés et peuvent fournir des informations utiles sur l'efficacité des stratégies d'échantillonnage.

Mots-clés : écologie aquatique / cycle diurne / systèmes lotiques / invertébrés benthique

\footnotetext{
^ Corresponding author: simone.guareschi@um.es

$\star \star$ These authors contributed equally to this work.
} 


\section{Introduction}

Several studies have stressed the importance of light variation and the influence of day/night conditions on plants and animals by examining both physiological and ecological points of view (e.g., Gerrish et al., 2009; Gaston et al., 2013). For instance for terrestrial insects, their distribution or features can markedly differ from day to night as a survival strategy to avoid insectivorous birds (e.g., Guevara and Avilés, 2013). Unlike limnological research on lacustrine zooplankton distributions, which has long since recognized that species use different habitats in the daytime than they do at nighttime (e.g., Hutchinson, 1967; Dodson, 1990), very little is known about riverine communities. This is especially true for no-target taxa for conservation policies like invertebrates (e.g. Cardoso et al., 2011).

Most of the information about freshwater macroinvertebrate ecology has been collected during daytime sampling activities. Biomonitoring activities on aquatic ecosystems, which are probably the commonest way to obtain constant aquatic macroinvertebrate samples and data, originate from fieldwork done in the daytime. Any nocturnal activity is usually avoided for safety reasons, and also given the logistical constraints on researchers and technicians. Existing studies that are directly related to light and darkness dynamics in streams have generally investigated the relationship between macroinvertebrate drift and the predatory activity of fish (e.g., Roussel et al., 1999; Davey et al., 2011; Conallin et al., 2012). In line with this, numerous macroinvertebrate taxa usually demonstrate a peak in drift activity related to darkness or nighttime conditions (e.g., Hansen and Closs, 2007).

Night is an important part of the diel cycle and several macroinvertebrates have demonstrated some form of nocturnal activity in different aquatic ecosystems (e.g. feeding or avoiding predation, Elliott 2000, 2002; Hampton and Duggan, 2003; Florencio et al., 2011). In a North American stream, for example, it has been observed that several caddisfly larvae (Sericostomatidae) burrow during the day and resurface at night (Bergey and Resh, 1994).

Previous experimental approaches on day/night changes in aquatic macroinvertebrate assemblages have focused mainly on specific species, such as freshwater crustaceans (Johnson and Covich, 2000; Elliot 2005a), EphemeropteraPlecoptera-Trichoptera taxa (Elliot, 2000, 2002) or gastropods (Lombardo et al., 2010). Likewise, marine and transitional (e.g., Guest et al., 2003) or lentic and temporary ecosystems (Marklund et al., 2001; Florencio et al., 2011) have been previously investigated, but less is known about riverine ecosystems and the entire stream macroinvertebrate community (see Copp et al., 2005, for an example in England).

This study evaluated and compared structural and functional metrics along the same river stretch, and different environmental variables were measured to: (i) provide a complete and quantitative assessment of day-to-night changes in the riverine macroinvertebrate community; (ii) assess the relevance of different environmental variables on macroinvertebrate compositions in different diel phases.

By addressing the first objective, we can gain an understanding of whether the biological and ecological information obtained during a specific period may be representative of the general condition. By dealing with the second objective, we can investigate if different environmental variables are specifically associated with macroinvertebrate community compositions in the daytime and/or at nighttime.

After considering the nocturnal activities of some aquatic taxa and that some physico-chemical stream variables (e.g. water dissolved oxygen, $\mathrm{pH}$ ) at night have been previously suggested as being capable of triggering nocturnal movements in lotic ecosystems (Wiley and Kohler, 1980; Brittain and Eikeland, 1988) we hypothesized that some discordances should be detected. We also expected to find main differences in the composition metrics values, such as aggregation. Similar results would demonstrate the consistency of the sampling data in any diel cycle stage.

Changes in macroinvertebrate distribution and diel variation are crucial for gaining a clearer understanding of population dynamics in aquatic ecosystems. Information on the diel activity patterns of macroinvertebrate larvae can enable us to understand the ecological role of particular taxa or groups, and may also prove useful when designing fieldwork studies and strategies. Throughout the article, we used the terms day and daytime to refer to daylight hours, and night and nighttime to refer to periods of darkness, which are in accordance with Helfman (1986).

\section{Methods}

\subsection{Study area}

This study was performed in the Lemme stream, a typical small-sized (length $35 \mathrm{~km}$ ) perennial Apennine stream tributary of the Orba stream (Po Basin, Piemonte Region, NW Italy). This kind of lotic ecosystem is widespread in continental and peninsular Italy as the Apennine Mountains extensively cover the country (Gumiero et al., 2009). Dense woodlands with small scattered urban areas cover the entire catchment, where riparian deciduous vegetation is abundant. The sampling site $\left(44^{\circ} 36^{\prime} 49.71^{\prime \prime} \mathrm{N} / 8^{\circ} 50^{\prime} 38.55^{\prime \prime} \mathrm{E}, 342 \mathrm{~m}\right.$ a.s.l.) is a representative 60 -meter long stretch, with a mixture of riffles and runs, no deep pools, but with a moderate and constant slope. Riverbed width is approximately $4.0-5.0 \mathrm{~m}$, and the substrate had the following particle composition: $10 \%$ sand, $30 \%$ gravel, $50 \%$ pebbles and $10 \%$ boulders (see Bo et al., 2007 for further details).

As artificial lights, or extended and simulated periods of light and dark conditions, can apparently influence stream communities and associated terrestrial ecosystems (e.g., Fuller et al., 1986; Perkin et al., 2011; Meyer and Sullivan, 2013), a pristine stretch, located far from homes and villages, was considered to avoid any effects of anthropogenic factors on field data.

\subsection{Biological and environmental data}

Macroinvertebrates were collected with a $33 \times 33 \mathrm{~cm}$ Surber sampler (255- $\mu \mathrm{m}$ mesh) from December 13 to 20 in 2011. On a daily basis, five Surber samples were taken near midday and five near midnight to avoid dates with a full moon 


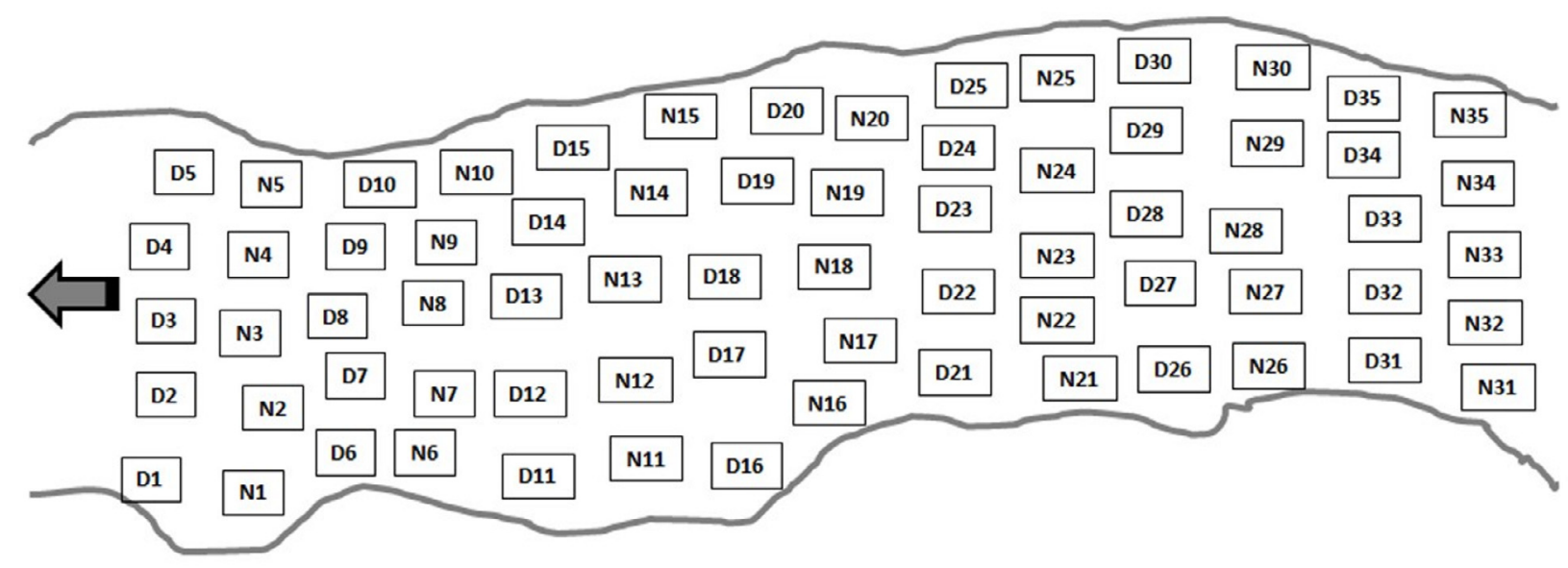

$60 \mathrm{~m}$

Fig. 1. Example of sampling strategy (Surber distribution) in the studied Lemme stream reach (D1-D35: daytime Surbers, N1-N35; nighttime Surbers). The gray arrow indicates flow direction.

in order to maximize variation at natural light levels between night and day. Similar schedules have been considered in other studies (e.g., Elliot, 2002). Fieldwork was conducted at the end of fall, a period during which invertebrate abundance and diversity are generally higher in these ecosystems following natural leaf fall (Bo and Fenoglio, 2011). The Surber sampler is a quantitative approach (data refer to the sampled surface area), and is the most widely used technique in macroinvertebrate research and stream biomonitoring in Italy. Sampling units were selected to obtain a complete representation of all the microhabitat types along the stretch. However, as benthic taxa are not expected to recolonize disturbed sediments as quickly as other aquatic taxa do (e.g. fish), nighttime sampling was done approximately $0.5 \mathrm{~m}$ upstream from the corresponding daytime sampling point (following Copp et al., 2005). By the time field activities had ended, 70 Surber units had been obtained along the studied stretch: 35 in the daytime (D) and 35 at nighttime (N) (Figure 1).

After collecting macroinvertebrates, they were preserved in $96 \%$ ethanol and identified in the laboratory at the family level using the taxonomic keys proposed by Tachet et al. (2010). The use of higher taxonomic levels (e.g. family) has been widely utilized in previous studies on invertebrates because of the high correlation between family and species richness (Bournaud et al., 1996; Baldi, 2003; Sánchez-Fernandez et al., 2006). Dolédec et al. (2000) evidenced minor differences in some functional traits, including dispersal, between macroinvertebrate taxonomic levels, and concluded that genus, and even the families level, can be suitable for describing many processes in macroinvertebrate communities. This can make measuring taxonomic richness and composition easier, which enables the study of the entire macroinvertebrate community. Moreover, macroinvertebrate family richness is generally considered one of the main biological metrics in aquatic ecosystem bioassessments (e.g. Birk et al., 2012).

The richness (No. of taxa), abundance (No. of individuals), composition, level of aggregation (Morisita Index), inver- tebrate biomass, biomonitoring results and indicator taxa were evaluated and compared. In order to complement our analysis and to consider functional information, each collected taxon was assigned to a functional feeding group (FFG: scrapers, shredders, gatherers, filterers and predators), as set out by Merritt and Cummins (1996). Each richness group value (No. individuals/group) was compared between D and N. Moreover, to obtain biomonitoring information, a test was run with the macroinvertebrate-based index STAR_ICMi. This is the official multimetric index used in Italy for assessing water course quality status according to European legislation (for further details, see Buffagni et al., 2006 and Buffagni and Erba, 2007). The index values were obtained and investigated for both the $\mathrm{D}$ and $\mathrm{N}$ periods.

To characterize the study areas and to assess the relevance of different factors, specific site variables (water velocity, depth, substrate size and coarse particulate organic matter (CPOM) amount) were measured at each sampling point (corresponding to each Surber) and were used in the multivariate analysis. Current velocity was measured with an Eijkelkamp 13.14 portable instrument, while the mean substrate diameter was calculated by weighing the mean diameter of all the mineral microhabitat sizes by the previously determined coverage percentage. The proportions of grain size classes on the surface area were visually estimated according to class as sand, gravel, microlithal, mesolithal, macrolithal and megalithal, as considered in the STAR_ICMi protocol adopted in Italy (Buffagni and Erba, 2007).

To quantify CPOM, leaves and other vegetal detritus (diameter $>1 \mathrm{~mm}$ ) were collected from each Surber sample. In the laboratory, this material was air-dried for $24 \mathrm{~h}$, oven-dried $\left(105^{\circ} \mathrm{C}\right.$ ) for $24 \mathrm{~h}$ and weighed on an electronic balance (accuracy $0.01 \mathrm{~g}$ ). The collected macroinvertebrate individuals were also oven-dried at $105^{\circ} \mathrm{C}$ for $4 \mathrm{~h}$, after which dry weight was recorded to obtain the macroinvertebrate biomass for each sample (accuracy $0.01 \mathrm{~g}$ ). 


\subsection{Statistical analysis}

To ensure that the results were consistent, the completeness of the entire taxa inventory generated was assessed using a nonparametric estimator (chao2, the "specpool" function of the R package "vegan"), as suggested by Walther and Moore (2005), which has already been used in macroinvertebrate community analyses (e.g., Martínez-Sanz et al., 2010).

To examine the diel differences in different community descriptors (abundance, family richness, Shannon Index, biomonitoring results and functional role richness), $t$-tests on the transformed data (log or square root) were run. Homoscedasticity and normal data distribution were not constituted (not even with numerous transformations) for variables "No. of scrapers" and "biomass". In these cases, analyses were performed by nonparametric Wilcoxon tests.

To investigate if the daytime and nighttime communities presented different aggregation levels, the Morisita Index of Intraspecific Aggregation (Morisita, 1959; Krebs, 1999) was resorted to. In order to assess the differences in the aggregation values between $\mathrm{D}$ and $\mathrm{N}$, we examined the differences obtained with what would be expected by chance alone. To do this, we compared the difference in the aggregation values obtained in our samples (D value $v s$. $\mathrm{N}$ value) with the difference obtained from 9999 random draws of an equal number of sampling sites taken from the entire pool of sites to obtain a $p$-value $(n=70$, including both daytime and nighttime).

A nonmetric multidimensional scaling (NMDS) analysis was performed to visualize possible dissimilarities or patterns between the macroinvertebrate communities from the different sampling periods (D or N) using the entire dataset (No. sites $=70$ ). Bray-Curtis distance was used as a dissimilarity measure, and stress was employed to test goodness of fit. Linear fittings, using the "envfit" function (vegan package, Oksanen et al., 2013), were performed between the environmental variables and the output of each NMDS ordination ( $\mathrm{D}$ and N, previously performed) to identify the environmental factors that drove the composition of macroinvertebrate communities at nighttime and in the daytime. The significance of the fitted vectors was assessed by a permutation procedure (9999 permutations). A Permanova analysis (Anderson, 2001) was carried out using Bray-Curtis distance to test whether there was a significant difference between the a priori proposed division (D and $\mathrm{N}$ ) in terms of macroinvertebrate communities.

The daytime STAR_ICMi value was obtained by considering the median value after 1000 randomizations of 10 Surber data (among 35 daytime Surbers). At the same time, the 2.5 and 97.5 percentiles were calculated to obtain the confidence interval (p.c.i.). The same procedure was followed using the nighttime Surber data to obtain a nighttime median STAR_ICMi value and its p.c.i..

Finally, an indicator value analysis (Dufrêne and Legendre, 1997) was carried out using the indicspecies package (De Cáceres and Legendre, 2009) to select the indicator family for each sampling period ( $\mathrm{D}$ and $\mathrm{N}$ ). This analysis evaluates the affinity of each taxon for each a priori-defined group and provides an indicator value (herein called IV). All the analyses were performed with the R 3.0.1 software of the R statistical environment (R Development Core Team, 2013).

\section{Results}

\subsection{Environmental characteristics and macroinvertebrates community}

The current velocity, depth, CPOM and mean diameter of the substrate of the studied stretch were $0.13 \pm 0.2 \mathrm{~m} \cdot \mathrm{s}^{-1}$, $18.23 \pm 9.6 \mathrm{~cm}, 2.32 \pm 2.9 \mathrm{~g}$ and $9.89 \pm 6.9 \mathrm{~cm}$, respectively (mean $\pm \mathrm{SD}$ ). No differences were observed between the $\mathrm{D}$ and $\mathrm{N}$ measurements ( $p>0.05$, nonparametric Wilcoxon test).

We collected and identified 21459 organisms of 50 macroinvertebrate higher taxa (49 families, plus Hydrachnidia, No. sites $=70$ ). The most abundant taxon was Chironomidae (Diptera), followed by Taeniopterygidae (Plecoptera), Simuliidae (Diptera), Hydropsychidae (Trichoptera) and Baetidae (Ephemeroptera). Each one had more than 500 individuals in all (Table 1). The nonparametric estimator of species richness (chao2) suggested that at least $90.9 \%$ (50 of 55) of the total number of expected taxa were recorded in our pool of sampling units. The results showed that the data sets compiled for the Lemme stream stretch (as a whole) could be considered realistically complete if compared to the values proposed by other authors (e.g., Jiménez-Valverde and Hortal, 2003; Sánchez-Fernández et al., 2008).

\subsection{Comparing day and night communities}

No differences were found between the daytime and nighttime assemblages for any studied community descriptor ( $t$-test results, Table 2), or for the invertebrate biomass or the number of scrapers present (Wilcoxon test $p=0.112$ and $p=0.833$, respectively). Forty-two taxa were obtained in the daytime and 46 at nighttime. The mean number of taxa in each Surber was strikingly similar under both conditions (mean $\pm \mathrm{SD}=11 \pm 3$ in the daytime; $11 \pm 4$ at nighttime). In both cases Chironomidae (Diptera) and Taeniopterygidae (Plecoptera) were the most abundant taxa. The biomass mean values for each Surber were $0.177 \mathrm{~g} \pm 0.08$ and $0.142 \mathrm{~g} \pm 0.10$ for $\mathrm{D}$ and $\mathrm{N}$, respectively. According to the intraspecific aggregation values obtained by the Morisita index, the daytime community gave a higher value (1.604) compared with the nighttime community (1.502). However, the difference (0.102) did not significantly differ from those obtained by chance after randomization (permutations test, $p>0.05$ ).

The NMDS ordinations of the macroinvertebrates communities (Figure 2, first two axes displayed) showed no clear clustered patterns, but the daytime and nighttime sites completely overlapped. The final stress value for the three-dimensional ordination was 0.19 . According to the 'envfit' analysis results, both communities ( $\mathrm{D}$ and $\mathrm{N}$ ) presented similar relationships to the environmental variables (Table 3 ). In each case, velocity was the most important variable to be related with community compositions in terms of explained data variance. However, the $r^{2}$ value obtained for the daytime community was higher $\left(r^{2}=0.58 v\right.$ s. $r^{2}=0.46$, Table 3$)$. This variable was followed by "CPOM values" for the nighttime community and by the "mean substrate diameter" for the daytime community (both with $p<0.01$, Table 3 ). 
Table 1. Taxa list and number of individuals obtained in the Lemme stream (Order and Family, except Hydrachnidia). D = daytime; $\mathrm{N}=$ nighttime (35 Surber in both cases).

\begin{tabular}{|c|c|c|c|}
\hline Order & Family & D abundance & $\mathrm{N}$ abundance \\
\hline \multirow[t]{6}{*}{ Plecoptera } & Capniidae & 3 & 3 \\
\hline & Chloroperlidae & 1 & 0 \\
\hline & Leuctridae & 75 & 71 \\
\hline & Nemouridae & 31 & 14 \\
\hline & Perlodidae & 0 & 2 \\
\hline & Taeniopterygidae & 670 & 894 \\
\hline \multirow[t]{5}{*}{ Ephemeroptera } & Baetidae & 265 & 272 \\
\hline & Caenidae & 0 & 2 \\
\hline & Ephemeridae & 2 & 3 \\
\hline & Heptageniidae & 21 & 17 \\
\hline & Leptophlebiidae & 21 & 11 \\
\hline \multirow[t]{11}{*}{ Trichoptera } & Beraeidae & 2 & 2 \\
\hline & Ecnomidae & 0 & 1 \\
\hline & Goeridae & 1 & 0 \\
\hline & Hydropsychidae & 298 & 248 \\
\hline & Hydroptilidae & 2 & 2 \\
\hline & Leptoceridae & 6 & 12 \\
\hline & Limnephilidae & 2 & 4 \\
\hline & Polycentropodidae & 3 & 1 \\
\hline & Psychomyidae & 13 & 9 \\
\hline & Rhyacophilidae & 96 & 113 \\
\hline & Sericostomatidae & 2 & 2 \\
\hline \multirow[t]{9}{*}{ Diptera } & Athericidae & 4 & 0 \\
\hline & Blephariceridae & 0 & 6 \\
\hline & Chironomidae & 9432 & 7610 \\
\hline & Empididae & 9 & 8 \\
\hline & Limoniidae & 62 & 51 \\
\hline & Psychodidae & 4 & 3 \\
\hline & Simuliidae & 144 & 577 \\
\hline & Stratiomyidae & 3 & 1 \\
\hline & Tipulidae & 3 & 4 \\
\hline \multirow[t]{5}{*}{ Coleoptera } & Dryopidae & 1 & 1 \\
\hline & Elmidae & 36 & 39 \\
\hline & Gyrinidae & 3 & 3 \\
\hline & Hydraenidae & 2 & 1 \\
\hline & Scirtidae & 1 & 0 \\
\hline \multirow[t]{2}{*}{ Odonata } & Aeshnidae & 5 & 6 \\
\hline & Gomphidae & 7 & 18 \\
\hline \multirow[t]{3}{*}{ Pulmonata } & Ancylidae & 1 & 3 \\
\hline & Lymnaeidae & 0 & 3 \\
\hline & Physidae & 1 & 1 \\
\hline Amphipoda & Gammaridae & 3 & 6 \\
\hline Isopoda & Asellidae & 0 & 2 \\
\hline Tubificida (Oligochaeta) & Naididae & 51 & 99 \\
\hline Opisthopora (Oligochaeta) & Lumbricidae & 6 & 6 \\
\hline Lumbriculida (Oligochaeta) & Lumbriculidae & 0 & 2 \\
\hline Arhynchobdellida & Erpobdellidae & 0 & 2 \\
\hline Tricladida & Dugesiidae & 6 & 8 \\
\hline Gordea (Nematoda) & Gordiidae & 1 & 3 \\
\hline Trombidiformes & Hydrachnidia & 8 & 6 \\
\hline
\end{tabular}


Table 2. Results of the $t$-test between the daytime and nighttime data. Variables "Scrapers" and "Biomass" are not displayed as they were evaluated with Wilcoxon tests (see the values and the results in the main text). $d f$ : degrees of freedom for the $t$-statistic.

\begin{tabular}{|l|c|c|c|}
\hline Variables & $d f$ & $t$ & $p$-value \\
\hline Abundances & 68 & -0.4269 & 0.6708 \\
\hline Families' Richness & 68 & -0.0329 & 0.9739 \\
\hline Shannon Index & 68 & 0.0838 & 0.9335 \\
\hline Predators (No. ind) & 67 & 0.9308 & 0.3553 \\
\hline Collectors (No. ind) & 67 & -0.9911 & 0.3252 \\
\hline Shredders (No. ind) & 67 & 0.6572 & 0.5133 \\
\hline Filter feeders (No. ind) & 68 & 0.0326 & 0.9741 \\
\hline
\end{tabular}

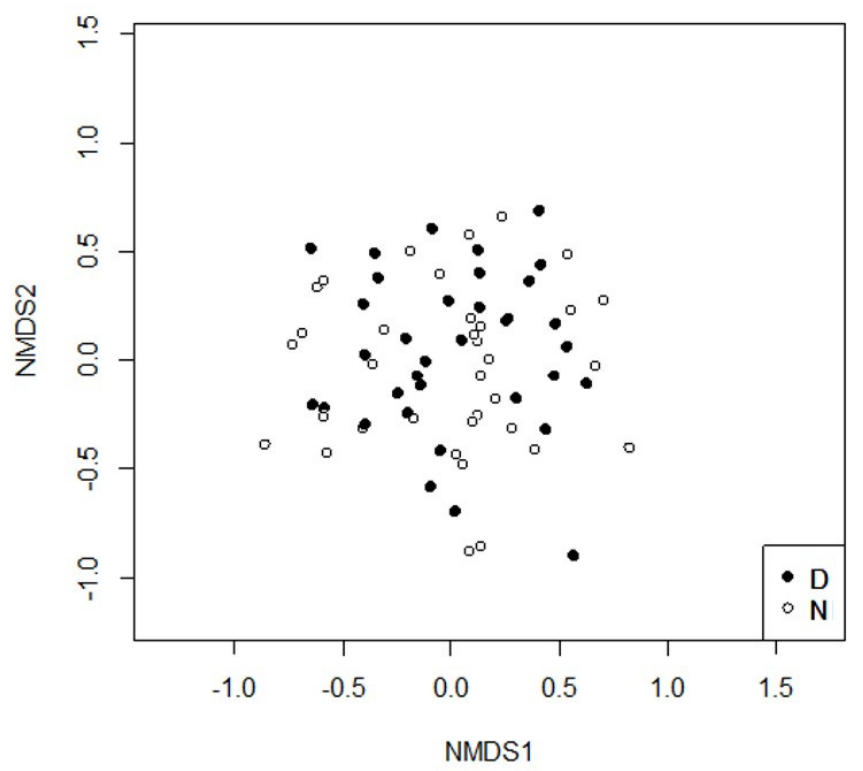

Fig. 2. NMDS plot where the a priori identified sites are colored. Black denotes the sites that belong to the daytime sampling $(n=35)$, while white indicates the sites that belong to the nighttime sampling $(n=35) .3 \mathrm{D}$ stress $=0.19$

The Permanova test showed no significant differences $(F$ value $\left.=0.50, r^{2}=0.01, p>0.05\right)$ in the macroinvertebrate assemblage composition between the two pre-defined groups (D and $\mathrm{N}$ ).

The median STAR_ICMi values were 0.960 and 0.985 for the $\mathrm{D}$ and the $\mathrm{N}$ period, respectively. In both cases, ecological status always varied between the Good and High classes, with a prevalence of the latter and their p.c.i. (0.866-1.059 and $0.855-1.085$, respectively) almost completely overlapping. Finally, the indicator value analysis did not identify strong groups of indicator taxa for the two community conditions under study ( $\mathrm{D}$ and $\mathrm{N}$ ). Only oligochaetes, which belong to the family Naididae, presented a high (IV $=0.49)$ and significant indicator value for the nighttime community $(p=0.036)$. No indicator taxa were obtained for the daytime community, and all the other families displayed low values with no significant relationships found in both cases.

\section{Discussion}

This study analyzed macroinvertebrate communities from daytime and nighttime samplings. No relevant differences were found when taxonomic, functional and biological information was considered. In this freshwater ecosystem (Northern Apennine stream), the information obtained at the family level (even for biomonitoring purposes) during a period (daytime or nighttime) was representative of the entire diel cycle and macroinvertebrate community.

When focusing on an intermittent small stream in Australia, Dell et al. (2015) recently obtained similar results, and detected no functional differences between the diurnal and nocturnal invertebrate communities in a specific experimental pool bed. Similarly, few or no diel differences in invertebrate densities were found in a British river (Copp et al., 2005).

Our findings contrast with our initial prediction. We suggest three potential reasons for the lack of major differences between the day and night data: (i) the heterotrophic condition of small-order streams (e.g., mid-mountain Apennine streams); (ii) presence of predators under both night and day conditions; (iii) absence of taxa with a specific phototaxis (e.g. positive phototaxis: movement toward light). The influence of these possibilities, either alone or combined, could be responsible for the results we obtained. Regarding the first reason, it is important to stress that allochthonous material (such as riparian leaves and wood) is a crucial energy source in these freshwater ecosystems (Allan and Castillo, 2007), and the source and availability of these components is largely independent of the light patterns that reach the aquatic system. A second reason could be the presence of different predators in the daytime and at nighttime, which could lead to similar predation pressure on macroinvertebrates. The confirmed presence of diurnal fish predators, such as brown trout (Salmo trutta, Linnaeus, 1758) and chub (Squalius cephalus, Linnaeus, 1758), could be balanced by the presence of nocturnal white-clawed crayfish (Austropotamobius pallipes complex), with abundant populations in the study area and in this watercourse (Zaccara et al., 2004; Nardi et al., 2005). Normally this crayfish has been considered an opportunistic omnivorous animal, but the importance of macroinvertebrates in its diet has been well documented in such ecosystems, and even in different life stages (Scalici and Gibertini, 2007). The third and last suggestion could be connected with the indicator values analysis results. In our case, the only nighttime indicator taxa were the oligochaetes of the family Naididae. This finding seems to indicate that taxa with a specific phototaxis were lacking. The wider distribution and greater abundance of these aquatic worms at nighttime has already been, be it indirectly, reported by Elliott (2005b), whose study analyzed gut content and the diet of a predaceous caddisfly. This could be related to the nocturnal habits of oligochaetes as a group. However, additional studies are essential before being able to recommend their use as indicator taxa.

When considering the second aim of this research work, we found very few differences when studying small-scale environmental variables. Velocity was the most important variable to be related with the macroinvertebrate composition in both cases. This variable has already been demonstrated as one of the most important factors of macroinvertebrate community 
Table 3. Correlations of environmental variables with the NMDS ordinations of macroinvertebrates (D and N separately) and the significance of the correlation based on the envfit function (9999 permutations). The goodness-of-fit statistic is the squared correlation coefficient $\left(r^{2}\right)$ (mean_diam $=$ mean riverbed substrate diameter).

\begin{tabular}{|l|c|c|c|c|c|c|}
\hline & \multicolumn{3}{|c|}{ Daytime (D) } & \multicolumn{5}{c|}{ Nighttime (N) } \\
\hline Variables & $r^{2}$ & $p$-value & & $r^{2}$ & $p$-value & \\
\hline Velocity & 0.578 & 0.0001 & $* * *$ & 0.457 & 0.0002 & $* * *$ \\
\hline Depth & 0.023 & 0.6831 & & 0.128 & 0.1129 & \\
\hline CPOM & 0.194 & 0.0305 & $*$ & 0.289 & 0.0048 & $* *$ \\
\hline mean_diam & 0.297 & 0.0033 & $* *$ & 0.075 & 0.2859 & \\
\hline
\end{tabular}

structures in different streams and regions (Boyero and Bailey, 2001; Brooks et al., 2005; Guareschi et al., 2014). The importance of the CPOM resource for stream macroinvertebrate distribution has been previously stressed in similar Apennine ecosystems, particularly in relation to shredders distribution (Fenoglio et al., 2005).

In our fieldwork study, the only difference found in terms of community composition and environmental variables was represented by the "mean riverbed substrate diameter" variable, which was relevant when considering the daytime data. The dependence of community structure on riverbed typology is a matter of constant debate (e.g., Culp et al., 1983; Barnes et al., 2013; Laini et al., 2014), although features like size, constitution or complexity have often been shown to influence macroinvertebrate diversity, structure or preferences in different streams and regions (e.g., Gayraud and Philippe, 2001; Graça et al., 2004; Barnes et al., 2013; Fu et al., 2015).

\subsection{Final remarks and future research lines}

In this kind of research, it is important to stress that some specific results may be affected by the sampling methods employed. For instance in lentic ecosystems, Florencio et al. (2011) suggested that dip-netting was especially appropriate for sampling macroinvertebrates in different microhabitats, whereas fyke nets were a better option for capturing nocturnal and fast-swimming invertebrates. Similar problems may affect lotic ecosystems, where the use of a Surber sampler alone might not be capable of collecting fast-swimming invertebrates like some Coleoptera (e.g., family Gyrinidae), or skaters like aquatic Hemiptera (e.g., Gerridae). We opted for the Surber sampler for both conditions because obtaining quantitative and comparable data was considered the most important factor and was in line with our study aims.

Nevertheless, more specific findings could probably be obtained by complementary methods to evaluate specific movements (e.g., traps or artificial substrates in different directions, Bruno et al., 2012) and to better comprehend the importance of each small scale variable. Further research is also required on the possibility of intra-stretch changes in macroinvertebrates distribution at nighttime by separately analyzing different habitats (e.g.: surface/bottom, sand/pebbles, sediment/macrophytes). For instance, by focusing on macrophyte patches (Ceratophyllum demersum) in an Argentinian stream, Ferreiro (2014) found a higher abundance value for invertebrates (planktonic and benthonic organisms) at nighttime, and suggested quite an abrupt change once the sun sets.
Our results potentially represent a reference and natural condition in Apennine streams as to day-night changes at the family level, and may provide useful information about sampling strategies. As behavioral adaptations may be speciesspecific, it would be interesting to compare these results by studying the entire macroinvertebrate community at a higher taxonomic resolution (e.g. species), despite this entailing having to make considerable efforts in terms of resources.

Coupling experimental approaches (laboratory) with fieldwork observations in different geographic areas is recommended. Complementary studies in urban streams and on the effects of light pollution are also advisable (Meyer and Sullivan, 2013), and even by considering different wavelengths (e.g., Barmuta el al., 2001) would be extremely interesting to better understand diel cycles in stream macroinvertebrates and their relationship with artificial pollution.

Acknowledgements. We thank native speakers Helen Warburton and Marie Palmer for proofreading this article and Andrea Rosati for his useful comments. Dr. Alex Laini was supported by a grant from "Consorzio dell'Oglio" (Italy).

\section{Conflict of interest}

The authors have declared no conflict of interest.

\section{References}

Allan J.D. and Castillo M.M., 2007. Stream Ecology: Structure and Function of Running Waters, 2nd ed., Springer, Dordrecht, The Netherlands, $436 \mathrm{p}$.

Anderson M.J., 2001. A new method for non-parametric multivariate analysis of variance. Austral Ecol., 26, 32-46.

Baldi A., 2003. Using higher taxa as surrogates of species richness: a study based on 3700 Coleoptera, Diptera and Acari species in Central-Hungarian reserves. Basic Appl. Ecol., 4, 589-593.

Barmuta L.A., Mckenny C.E.A. and Swain R., 2001. The responses of a lotic mayfly Nousia sp. (Ephemeroptera: Leptophlebiidae) to moving water and light of different wavelengths. Freshw. Biol., 46, 567-573.

Barnes J.B., Vaughan I.P. and Ormerod S.J., 2013. Reappraising the effects of habitat structure on river macroinvertebrates. Freshw. Biol., 58, 2154-2167.

Bergey E.A. and Resh V. H., 1994. Effects of burrowing by a stream caddisfly on case-associated algae. J. N. Am. Benthol. Soc., 13, 379-390. 
Birk S., Bonne W., Borja A., Brucet S., Courrat A., Poikane S., Solimini A., vande Bund W., Zampoukas N. and Hering D., 2012. Three hundred ways to assess Europe's surface waters: an almost complete overview of biological methods to implement the Water Framework Directive. Ecol. Indic., 18, 31-41.

Bo T. and Fenoglio S., 2011. Impacts of a micro-sewage effluent on the biota of a small Apennine creek. J. Freshw. Ecol., 26, 537545.

Bo T., Fenoglio S., Malacarne G., Pessino M. and Sgariboldi F., 2007. Effect of clogging on stream macroinvertebrates: an experimental approach. Limnologica, 37, 186-192.

Bournaud M., Cellot B., Richoux P. and Berrahou A., 1996. Macroinvertebrate community structure and environmental characteristics along a large river: congruity of patterns for identification to species or family. J. N. Am. Benthol. Soc., 15, 232-253.

Boyero L. and Bailey R.C., 2001. Organization of macroinvertebrate communities at a hierarchy of spatial scales in a tropical stream. Hydrobiologia, 464, 219-225.

Brittain J.E. and Eikeland T.J., 1988. Invertebrate Drift - A Review. Hydrobiologia, 166, 77-93.

Brooks A.J., Haeusler T.I.M., Reinfelds I. and Williams S., 2005. Hydraulic microhabitats and the distribution of macroinvertebrate assemblages in riffles. Freshw. Biol., 50, 331-334.

Bruno M.C., Bottazzi E. and Rossetti G., 2012. Downward, upstream or downstream? Assessment of meio-and macrofaunal colonization patterns in a gravel-bed stream using artificial substrates. Ann. Limnol. - Int. J. Lim., 48, 371-381.

Buffagni A. and Erba S., 2007. Macroinvertebrati acquatici e Direttiva 2000/60/ EC (WFD). Parte A. Metodo di campionamento per i fiumi guadabili. Resource document. IRSA-CNR. 118 p. Available from: http://www.irsa.cnr.it/Docs/Notiz/notiz2007_\%2803\%29. pdf. (In Italian, accessed 17 February 2015).

Buffagni A., Erba S., Cazzola M., Murray-Bligh J., Soszka H. and Genoni P., 2006. The Star common metrics approach to the WFD intercalibration process: full application for small, lowland rivers in three European countries. Hydrobiologia, 566, 379-399.

Cardoso P., Erwin T.L., Borges P.A. and New T.R., 2011. The seven impediments in invertebrate conservation and how to overcome them. Biol. Conserv., 144, 2647-2655.

Conallin J., Jyde M., Filrup K. and Pedersen S., 2012. Diel foraging and shelter use of large juvenile brown trout (Salmo trutta) under food satiation. Knowl. Manag. Aquat. Ecosyst., 404, 05.

Copp G.H., Spathari S. and Turmel M., 2005. Consistency of diel behaviour and interactions of stream fishes and invertebrates during summer. River Res. Appl., 21, 75-90.

Culp J.M., Walde S.J. and Davies R.W., 1983. Relative importance of substrate particle size and detritus to stream benthic macroinvertebrate microdistribution. Can. J. Fish Aquat. Sci., 40, 15681574.

Davey A.J., Booker D.J. and Kelly D.J., 2011. Diel variation in stream fish habitat suitability criteria: implications for instream flow assessment. Aquat. Conserv. 21, 132-145.

De Cáceres M. and Legendre P., 2009. Associations between species and groups of sites: indices and statistical inference. Ecology, 90, 3566-3574.

Dell A.I., Zhao L., Brose U., Pearson R.G. and Alford R.A., 2015. Population and community body size structure across a complex environmental gradient. Adv. Ecol. Res., 52, 115-167.

Dodson S., 1990. Predicting diel vertical migration of zooplankton. Limnol. Oceanogr., 35, 1195-1200

Dolédec S., Olivier J.M. and Statzner B., 2000. Accurate description of the abundance of taxa and their biological traits in stream invertebrate communities: effects of taxonomic and spatial reso- lution. Archiv für Hydrobiologie - Fundam. Appl. Limnol., 148, 25-43.

Dufrêne M. and Legendre P., 1997. Species assemblages and indicator species: the need for a flexible asymmetrical approach. Ecol. Monogr., 67, 345-366.

Elliott J.M., 2000. Contrasting diel activity and feeding patterns of four species of carnivorous stoneflies. Ecol. Entomol., 25, 26-34.

Elliott J.M., 2002. A quantitative study of day-night changes in the spatial distribution of insects in a stony stream. J. Anim. Ecol., $71,112-122$.

Elliott J.M., 2005a. Day-night changes in the spatial distribution and habitat preferences of freshwater shrimps, Gammarus pulex, in a stony stream. Freshw. Biol., 50, 552-566.

Elliott J.M., 2005b. Contrasting diel activity and feeding patterns of four instars of Rhyacophila dorsalis (Trichoptera). Freshw. Biol., 50, 1022-1033.

Fenoglio S., Bo T., Agosta P. and Malacarne G., 2005. Temporal and spatial patterns of coarse particulate organic matter and macroinvertebrate distribution in a low-order Apennine stream. J. Freshw. Ecol., 20, 539-547.

Ferreiro N., 2014. Evidence on Night Movements of Macroinvertebrates to Macrophytes in a Pampean Stream. Open J. Mod. Hydrol., 4, 95-100.

Florencio M., Díaz-Paniagua C., Gomez-Mestre I. and Serrano L., 2011. Sampling macroinvertebrates in a temporary pond: comparing the suitability of two techniques to detect richness, spatial segregation and diel activity. Hydrobiologia, 689, 121-130.

Fu L., Jiang Y., Ding J., Liu Q., Peng Q.Z., Kang M.Y. and Wang L.Z., 2015. Spatial variation of macroinvertebrate community structure and associated environmental conditions in a subtropical river system of southeastern China. Knowl. Manag. Aquat. Ecosyst., 416, 17.

Fuller R.L., Roelofs J.R. and Fry T.J., 1986. The importance of algae to stream invertebrates. J. N. Am. Benthol. Soc., 5, 290-296.

Gaston K.J., Bennie J., Davies T.W. and Hopkins J., 2013. The ecological impacts of nighttime light pollution: a mechanistic appraisal. Biol. Rev., 88, 912-927.

Gayraud S. and Philippe M., 2001. Does subsurface interstitial space influence general features and morphological traits of the benthic macroinvertebrate community in streams? Archiv für Hydrobiologie - Fundam. Appl. Limnol., 151, 667-686.

Gerrish G.A., Morin J.G., Rivers T.J. and Patrawala Z., 2009. Darkness as an ecological resource: the role of light in partitioning the nocturnal niche. Oecologia, 160, 525-536.

Graça M.A., Pinto P., Cortes R., Coimbra N., Oliveira S., Morais M., Carvalho M.J. and Malo J., 2004. Factors Affecting Macroinvertebrate Richness and Diversity in Portuguese Streams: a Two Scale Analysis. Int. Rev. Hydrobiol., 89, 151-164.

Guareschi S., Laini A., Racchetti E., Bo T., Fenoglio S. and Bartoli M., 2014. How do hydromorphological constraints and regulated flows govern macroinvertebrate communities along an entire lowland river? Ecohydrology, 7, 366-377.

Guest M.A., Connolly R.M. and Loneragan N.R., 2003. Seine nets and beam trawls compared by day and night for sampling fish and crustaceans in shallow seagrass habitat. Fish. Res., 64, 185 196.

Guevara J. and Avilés L., 2013. Community-wide body size differences between nocturnal and diurnal insects. Ecology, 94, 537543 . 
Gumiero B., Maiolini B., Rinaldi M., Surian N., Boz B. and Moroni F., 2009. The Italian Rivers. In: Rivers of Europe. Academic Press, Amsterdam, 467-495.

Hampton S.E. and Duggan I.C., 2003. Diel habitat shifts of macrofauna in a fishless pond. Mar. Freshwater Res., 54, 797-805.

Hansen E.A. and Closs G.P., 2007. Temporal consistency in the longterm spatial distribution of macroinvertebrate drift along a stream reach. Hydrobiologia, 575, 361-371.

Helfman G.S., 1986. Fish behaviour by day, night and twilight. In: The behaviour of teleost fishes. Springer, USA, 366-387.

Hutchinson G.E., 1967. A treatise on limnology, Wiley, New York, Vol. 2, $1115 \mathrm{p}$.

Jiménez-Valverde A. and Hortal J., 2003. Las curvas de acumulación de especies y la necesidad de evaluar la calidad de los inventarios biológicos. Rev. Ibérica Aracnol., 8, 151-161.

Johnson S.L. and Covich A.P., 2000. The importance of night-time observations for determining habitat preferences of stream biota. Regul. River., 16, 91-99.

Krebs C.J., 1999. Ecological Methodology, 2nd ed., Addison-Wesley Educational Publishers, Menlo Park, 624 p.

Laini A., Vorti A., Bolpagni R. and Viaroli P., 2014. Small-scale variability of benthic macroinvertebrates distribution and its effects on biological monitoring. Ann. Limnol. - Int. J. Lim., 50, 211 216.

Lombardo P., Miccoli F.P., Giustini M. and Cicolani B., 2010. Diel activity cycles of freshwater gastropods under natural light: patterns and ecological implications. Ann. Limnol. - Int. J. Lim., 46, 29-40.

Marklund O., Blindow I. and Hargeby A., 2001. Distribution and diel migration of macroinvertebrates within dense submerged vegetation. Freshw. Biol., 46, 913-924.

Martínez-Sanz C., García-Criado F., Aláez C.F. and Aláez M.F., 2010. Assessment of richness estimation methods on macroinvertebrate communities of mountain ponds in Castilla y León (Spain). Ann. Limnol. - Int. J. Lim., 46, 101-110.

Merritt R.W. and Cummins K.W., 1996. An introduction to the aquatic insects of North America, 3rd ed., Kendall/Hunt, Dubuque, IO, $862 \mathrm{p}$.

Meyer L.A. and Sullivan S.M.P., 2013. Bright lights, big city: influences of ecological light pollution on reciprocal stream-riparian invertebrate fluxes. Ecol. Appl., 23, 1322-1330.

Morisita M., 1959. Measuring of the dispersion of individuals and analysis of the distributional patterns. Mem. Fac. Sci. Kyushu Univ. Ser. E 2, 215-235.

Nardi P.A., Bernini F., Bo T., Bonardi A., Fea G., Ghia D., Negri A., Razzetti E., Rossi S. and Spairani M. 2005. Status of
Austropotamobius pallipes complex in the watercourses of the Alessandria province (NW Italy). Bull. Fr. Pêche Piscic., 376377, 585-598.

Oksanen J., Guillaume Blanchet F., Kindt R., Legendre P., Minchin P.R., O'Hara R.B., Simpson G.L., Solymos P., Henry M., Stevens H. and Wagner H., 2013. Vegan: Community Ecology Package. R package version 2.0-8. Available from: http://CRAN.R-project. org/package $=$ vegan.

Perkin E.K., Hölker F., Richardson J.S., Sadler J.P., Wolter C. and Tockner K., 2011. The influence of artificial light on stream and riparian ecosystems: questions, challenges, and perspectives. Ecosphere 2, art. 122.

R Development Core Team, 2013. R: A language and environment for statistical computing. R Foundation for Statistical Computing, Vienna, Austria. Available from: http://www.R-project.org/ (accessed 23 December 2014).

Roussel J.M., Bardonnet A. and Claude A., 1999. Microhabitats of brown trout when feeding on drift and when resting in a lowland salmonid brook: effects on weighted usable area. Archiv für Hydrobiologie - Fundam. Appl. Limnol., 146, 413-429.

Sánchez-Fernández D., Abellán P., Mellado A., Velasco J. and Millán A., 2006. Are water beetles good indicators of biodiversity in Mediterranean aquatic ecosystems? The case of Segura river basin (SE Spain). Biodivers. Conserv., 15, 4507-4520.

Sánchez-Fernández D., Lobo J.M., Abellán P., Ribera I. and Millán A., 2008. Bias in freshwater biodiversity sampling: the case of Iberian water beetles. Divers. Distrib., 14, 754-762.

Scalici M. and Gibertini G., 2007. Feeding habits of the crayfish Austropotamobius pallipes (Decapoda, Astacidae) in a brook in Latium (central Italy). Ital. J. Zool., 74, 157-168.

Tachet H., Richoux P., Bournaud M. and Usseglio-Polatera P., 2010. Invertébrés d'eau douce: systématique, biologie, écologie, CNRS Editions, Paris, France, 588 p.

Walther B.A. and Moore J.L., 2005. The concepts of bias, precision and accuracy, and their use in testing the performance of species richness estimators, with a literature review of estimator performance. Ecography, 28, 815-829.

Wiley M.J. and Kohler S., 1980. Positioning Changes of Mayfly Nymphs Due to Behavioral Regulation of Oxygen Consumption. Can. J. Zool., 58, 618-622.

Zaccara S., Stefani F., Galli P., Nardi P. A. and Crosa G. 2004. Taxonomic implications in conservation management of white-clawed crayfish (Austropotamobius pallipes) (Decapoda, Astacidae) in Northern Italy. Biol. Conserv., 120, 1-10.

Cite this article as: S. Guareschi, A. Laini, S. Fenoglio, M. Paveto, T. Bo, 2016. Change does not happen overnight: a case study on stream macroinvertebrates. Knowl. Manag. Aquat. Ecosyst., 417, 21. 